\title{
Biodegradation of phenoxyacetic acid in soil by Pseudomonas putida PP0301(pR0103), a constitutive degrader of 2,4-dichlorophenoxyacetate
}

\author{
K. A. SHORT* ${ }^{*}$, R. J. KING ${ }^{\dagger}$, R. J. SEIDLER* and R. H. OLSEN ${ }^{\ddagger}$ \\ *USEPA Environmental Research Laboratory, 200 SW 35th Street, Corvallis, 'NSI Technology Services Corp., Environmental \\ Sciences, USEPA Environmental Research Laboratory, Coroallis, OR 97333 and ${ }^{\ddagger}$ Department of Microbiology and Immunology, \\ University of Michigan Medical School, Ann Arbor, MI 48109, USA
}

\begin{abstract}
The efficacy of using genetically engineered microbes (GEMs) to degrade recalcitrant environmental toxicants was demonstrated by the application of Pseudomonas putida PP0301(pR0103) to an Oregon agricultural soil amended with $500 \mu \mathrm{g} / \mathrm{g}$ of a model xenobiotic, phenoxyacetic acid (PAA). P. putida PP0301(pR0103) is a constitutive degrader of 2,4-dichlorophenoxyacetate (2,4-D) and is also active on the non-inducing substrate, PAA. PAA is the parental compound of 2,4-dichlorophenoxyacetic acid (2,4-D) and whilst the indigenous soil microbiota degraded $500 \mu \mathrm{g} / \mathrm{g}$ 2,4-D to less than $10 \mu \mathrm{g} / \mathrm{g}$, PAA degradation was insignificant during a 40-day period. No significant degradation of PAA occurred in soil inoculated with the parental strain P. putida PP0301 or the inducible 2,4D degrader $P$. putida PP0301(pR0101). Moreover, co-amendment of soil with 2,4-D and PAA induced the microbiota to degrade 2,4-D; PAA was not degraded. P. putida PP0301(pR0103) mineralized 500- $\mu \mathrm{g} / \mathrm{g}$ PAA to trace levels within 13 days and relieved phytotoxicity of PAA to Raphanus sativus (radish) seeds with $100 \%$ germination in the presence of the GEM and 7\% germination in its absence. In unamended soil, survival of the plasmid-free parental strain $P$. putida PP0301 was similar to the survival of the GEM strain $P$. putida PP0301(pR0103). However, in PAA amended soil, survival of the parent strain was over 10 000-fold lower $(<3$ colony forming units per gram of soil) than survival of the GEM strain after 39 days.
\end{abstract}

Keywords: biodegradation, soil, PAA, 2,4-D, GEM, pseudomonad

Received 17 January 1992; accepted 29 March 1992

\section{Introduction}

Bacterial degradation of phenoxyacetic acid (PAA) has been described in liquid culture studies with mutants of Alcaligenes eutrophus JMP134(pJP4) (Don \& Pemberton 1981; Pemberton et al. 1979) and recently in the genetically altered P. putida PP0300(pR0103) strain (Harker et al. 1989). Plasmid $p R 0103$ carries most of the genes for degradation of 2,4-dichlorophenoxyacetic acid $(2,4 \mathrm{D})$ and 3-chlorobenzoate (Don et al. 1985) and is deregulated for TFD degradation due to a deletion of a negative regulatory gene, tfdR (Kaphammer et al. 1990). The tfdR gene negatively regulates expression of the $t f d A$ gene product,

Correspondence: K. A. Short, Bioprocess Research and Development, Unit 1400-89-1, The Upjohn Company, Kalamazoo, MI 49001, USA tfd monoxygenase (Don et al. 1985; Streber et al. 1987; Harker et al. 1989). The deregulated $t f d$ monooxygenase recognizes the non-inducing substrate $P A A$ and converts PAA to phenol. P. putida strains PPO300(pR0103) and PP0301(pR0103) express a phenol hydroxylase and use PAA as a sole source of carbon (Harker et al. 1989; King et al. 1991).

The use of $P$. putida PP0301(pR0103) to degrade 2,4-D in different soil types has previously been demonstrated (Short et al. 1990, 1991; Doyle et al. 1991). In the present study, the ability of P. putida PP0301(pR0103) to degrade PAA was tested in soil. PAA is not directly used as an agricultural herbicide. Therefore, the purpose of this research was to demonstrate the potential use of GEMs to remediate chemically contaminated soil, and to provide 
further information on the environmental fate and activity of GEMs.

P. putida PP0301, the inducible 2,4-D degrader $P$. putida PP0301(pR0101), and the constitutive 2,4-D degrader P. putida PP0301 (pR0103) were added to a PAA-amended agricultural soil with a natural bacterial population capable of degrading 2,4-D (Short et al. 1990). PAA was recalcitrant to native 2,4-D degraders and to the inducible 2,4-D degrader $P$. putida PP0301 (pR0101). In addition, although PAA has been reported to be non-herbicidal (Cole \& Loughman, 1982), we present evidence that PAA is phytotoxic and toxic to bacteria.

\section{Materials and methods}

\section{Bacterial cultures}

'P. putida strains PP0301, PP0301(pR0101) and PP0301(pR0103) are resistant to nalidixic acid (nal) $(500 \mu \mathrm{g} / \mathrm{ml})$. P. putida PP0301 was derived from P. putida PPO300 (ATCC17514) by sequential transfer of naturally resistant subclones onto increasing concentrations of nalsupplemented medium (unpublished data). Plasmids pR0101 and pR0103 were derived from plasmid pJP4 (Don \& Pemberton 1981) as described previously (Harker et al. 1989), and in addition to carrying the genes for degradation of 2,4-D, they encode the degradation of 3-chlorobenzaate, resistance to mercury $(\mathrm{Hg})$ and tetracycline (tet) (located on transposon Tn1712) (Altenucher et al. 1983). Plasmid pR0103 was derived from plasmid pR0101 (Harker et al. 1989) by a serendipitous deletion of the trdR regulatory gene (Kaphammer et al. 1990). In minimal phosphate-buffered medium (Stanier et al. 1966), PP0301(pR0103) used PAA as a sole source of carbon (King et al. 1991).

\section{Bacterial culturing and preparation of soil}

To initiate each experiment, frozen $\left(-80^{\circ} \mathrm{C}\right)$ stock cultures were plated on the appropriate selective medium. $P$. putida PP0301 was plated onto nutrient medium (Olsen \& Shipley 1973) supplemented with 500- $\mu \mathrm{g} / \mathrm{ml}$ nal (Sigma Chemical Co., St Louis, Miss.). P. putida strains PP0301(pR0101) and PP0301(pR0103) were plated onto brainheart infusion medium (Difco Chemical Co., St Louis) supplemented with $25-\mu \mathrm{g} / \mathrm{ml} \mathrm{HgCl}_{2}$ (Aldrich Chemical Co., Milwaukee, Wisc.). Cultures were incubated overnight at $30^{\circ} \mathrm{C}$. The next day, several isolated colonies were used to inoculate $125 \mathrm{ml}$ of nutrient broth in a $250-\mathrm{ml}$ Erlenmeyer flask. Cultures were shaken overnight at 200 $\mathrm{rpm} g$ at $30^{\circ} \mathrm{C}$. Cells were pelleted by centrifugation at $8000 \mathrm{~g}$ for $10 \mathrm{~min}$ and washed twice in $200 \mathrm{ml}$ of $50-\mathrm{mm}$ $\mathrm{K}_{2} \mathrm{HPO}_{4} / \mathrm{NaH}_{2} \mathrm{PO}_{4}$ buffer ( $\mathrm{pH}$ 6.8). The final cell pellet
Table 1 Chemical characteristics of the soil

\begin{tabular}{lc}
\hline Variable & Measured value \\
\hline $\mathrm{pH}$ & 6.1 \\
Total organic carbon $(\%)$ & 4.41 \\
Total $\mathrm{N}(\%)$ & 0.19 \\
$\mathrm{P}(\mu \mathrm{g} / \mathrm{g})$ & 21 \\
$\mathrm{~K}(\mu \mathrm{g} / \mathrm{g})$ & 390 \\
$\mathrm{NO}_{3}^{-}(\mu \mathrm{g} / \mathrm{g})$ & 41.9 \\
$\mathrm{NH}_{4}(\mu \mathrm{g} / \mathrm{g})$ & 10.9 \\
$\mathrm{Cation}$ exchange capacity (mequiv $/ \mathrm{kg})$ & 198 \\
$\mathrm{Ca}($ mequiv $/ \mathrm{kg})$ & 132 \\
$\mathrm{Mg}$ (mequiv/kg) & 19.5 \\
\hline
\end{tabular}

was resuspended in $30 \mathrm{ml}$ of buffer prior to topical application of suspended cells to the soil surface.

\section{Soil characteristics, preparation and incubation}

The soil used in this study was collected from a farm in the foothills of the Oregon Coastal Mountain Range in the Willamette Valley, Oregon, USA. The soil is classified as a Veneta series, characterized by a $48-\mathrm{cm}$ surface layer of Veneta silt loam and silty clay loam. The chemical characteristics, as determined by the Oregon State University Soil Testing Laboratory, are shown in Table 1. Prior to inoculation or addition of liquid, the soil was first passed through a 2-mm-mesh-size seive. The first soil group-uninoculated soil-was wetted with buffer and amended with PAA or PAA and 2,4-D, mixed and brought to $-33-\mathrm{kPa}$ water tension (Orchard \& Cook 1983). The second soil group-unamended and inoculated soilwas inoculated with washed suspensions of $P$. putida strains PP0301, PP0301(pR0101) or PP0301(pR0103) and adjusted to $-33-\mathrm{kPa}$ water tension (Orchard \& Cook 1983). A third soil group-amended and inoculated soil was amended with PAA, inoculated with $P$. putida strains PP0301, PP0301(pR0101) or PP0301(pR0103), mixed, and adjusted to $-33-\mathrm{kPa}$ water tension. PAA was added at $500 \mu \mathrm{g} / \mathrm{g}$ of soil (free acid, $99 \%$ pure, Sigma Chem. Co.) as a dry powder or as a $1 \%$ solution in water ( $\mathrm{pH} 7.0$ ). 2,4-D was added at $500 \mu \mathrm{g} / \mathrm{g}$ (Aldrich Chem. Co) as a dry powder. These concentrations of chemical were chosen based on similar or higher dose rates of 2,4-D in other studies (Ou et al. 1978; Sattar \& Paasivirta 1980; Stott et al. 1983). All soils were placed in Petri dishes and incubated at room temperature in a humidified chamber.

\section{Seed germination}

Soil was first amended with $500-\mu g / g$ PAA and either uninoculated are inoculated by mixing with a washed cell 
suspension of $P$. putida strains PP0301, PP0301(pR0101) or PP0301(pR0103). The soil was then placed within Petri dishes and seeded with Raphanus sativus (radish), cultivar Cherry Belle Short Top. The dishes were covered to minimize evaporation and incubated at room temperature in a lighted humidified chamber. For these experiments, five seeds were placed within each dish and there were 3 dishes per condition. The dishes were monitored daily for seed germination and appearance of dicotyledonous leaves. In the absence of PAA, 100\% (15 out of 15) of the seeds germinated.

\section{Soil sampling}

Bacterial cell numbers were determined by vortexing, in triplicate, $1.0 \mathrm{~g}$ of soil in a final volume of $10 \mathrm{ml}$ of $\mathrm{H}_{2} \mathrm{O}$, serially diluted to a $10^{8}$ dilution and spread-plated, in duplicate for each dilution, onto nutrient medium supplemented with $(500-\mu \mathrm{g} / \mathrm{ml})$ nal. For determination of low numbers of bacteria, $1 \mathrm{~g}$ of soil was mixed with $2 \mathrm{ml}$ of $\mathrm{H}_{2} \mathrm{O}$ and plated directly or serially diluted prior to plating. Preservation of plasmidencoded mercury resistance was assessed by replica plating nal-resistant colonies onto brain-heart infusion medium supplemented with 25- $\mu \mathrm{g} /$ $\mathrm{ml} \mathrm{HgCl}$. There was no evidence for loss of plasmid in either chemically unamended or PAA-amended soil.

\section{Extraction of PAA, Phenol and 2,4-D}

A $2.0-\mathrm{g}$ soil subsample was placed in a $30-\mathrm{ml}$ screw-top test tube with a Teflon-lined cap. The initial alkaline extraction of soil was performed as described previously (Purkayastha 1974; Jensen 1978; Short et al. 1990). Subsequent extraction was conducted as described by Smith et al. (1984) except that diethyl ether was substituted for chloroform.

\section{Analysis of PAA, phenol and 2,4-D}

Ether soil extract samples were analysed for PAA and phenol content with an HP-1090 high-performance liquid chromatograph (HPLC) (Hewlett-Packard Co., Avondale, Penn.) coupled to a diode-array UV detector. Samples were separated by an isocratic mobile phase $\left(35 \% \mathrm{H}_{2} \mathrm{O}\right.$, $65 \% \mathrm{CH}_{3} \mathrm{OH}, 0.1 \% \mathrm{CH}_{3} \mathrm{COOH}$ ) on a $\mathrm{C} 18$ reverse-phase micro-bore and guard column at a flow rate of $1.0 \mathrm{ml} / \mathrm{min}$. Sample absorbance was monitored at 254, 272 and $280 \mathrm{~nm}$. External PAA, phenol and 2,4-D reference standards (NBS certified, Research Triangle, N.C.) were incorporated to bracket samples and analysed in triplicate every tenth sample. The limit of detection for PAA, phenol and 2,4-D using HPLC was $0.1 \mu \mathrm{g}$. Extraction efficiency for soil used in two experimental runs was $60 \%$ and $66 \%$ for PAA and 2,4-D, respectively. All values are reported without adjustment for extraction efficiency. Unless otherwise stipulated, chemicals used in extraction and analysis of PAA and 2,4-D were of Analytical Reagent (AR) grade (Aldrich Chemical Co.). The extraction efficiency of PAA added to sterile soil was initially $60 \%$ and did not change over a 3-week period.

\section{Statistical analysis}

Data for bacterial survival and chemical extraction of PAA were analysed for statistical significance by comparison of mean daily values using the Tukey-Kramer method (SAS Institute Inc. Cary, N.C.). $P$ values $\leqslant 0.05$ were considered significant. Seed germination data was analysed for statistical significance by the Fisher's exact test (Steel \& Torrie 1980). Plotted values are the means \pm SEM.

\section{Results}

Degradation of PAA occurred only in the presence of the GEM strain, P. putida PP0301(pR0103). After 28 days, there was no significant degradation of PAA in soil inoculated with either the parental strain P. putida PP0301 or the regulated 2,4-D degrader strain $P$. putida PP0301(pR0101) (Fig. 1). The indigenous soil microbiota had not degraded any PAA after 40 days' incubation (data not shown). The co-amendment of $500 \mu \mathrm{g}$ of 2,4-D per $\mathrm{g}$ of soil and $150 \mu \mathrm{g}$ of PAA per $g$ of soil did not result in metabolism of PAA. After 40 days' incubation, no 2,4-D

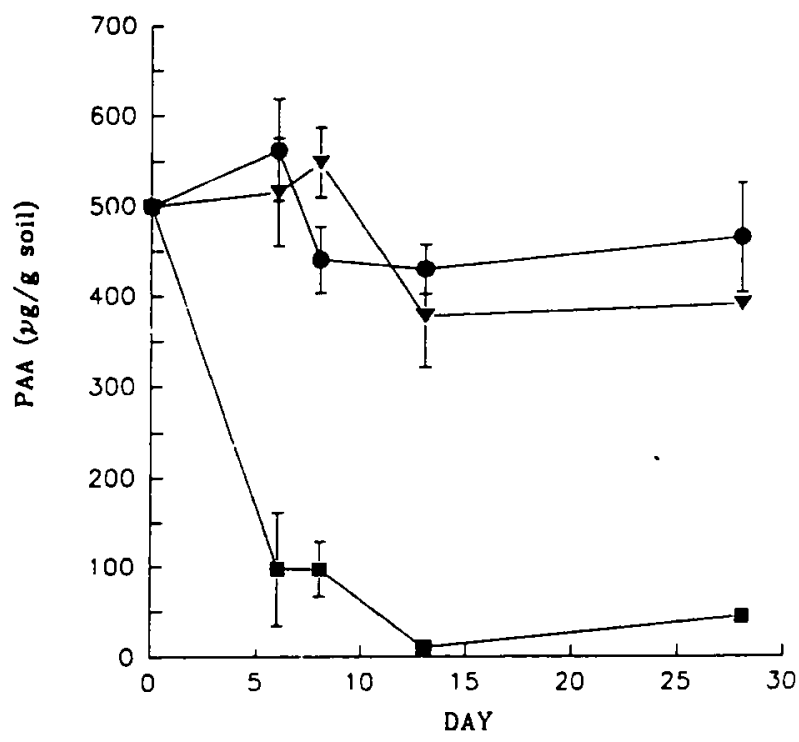

Fig. 1 Degradation of phenoxyacetic acid in an agricultural soil. Soil was inoculated with P. putida PPO301 (O), P. putida PP0301(pR0101) ( $\mathbf{\nabla}$ ), or $P$. putida PP0301 (pR0103) (ם) at approximately $10^{8} \mathrm{CFU} / \mathrm{g}$ of soil. Plotted values are means \pm SEM. Some standard error bars fall within the area of the symbol. 

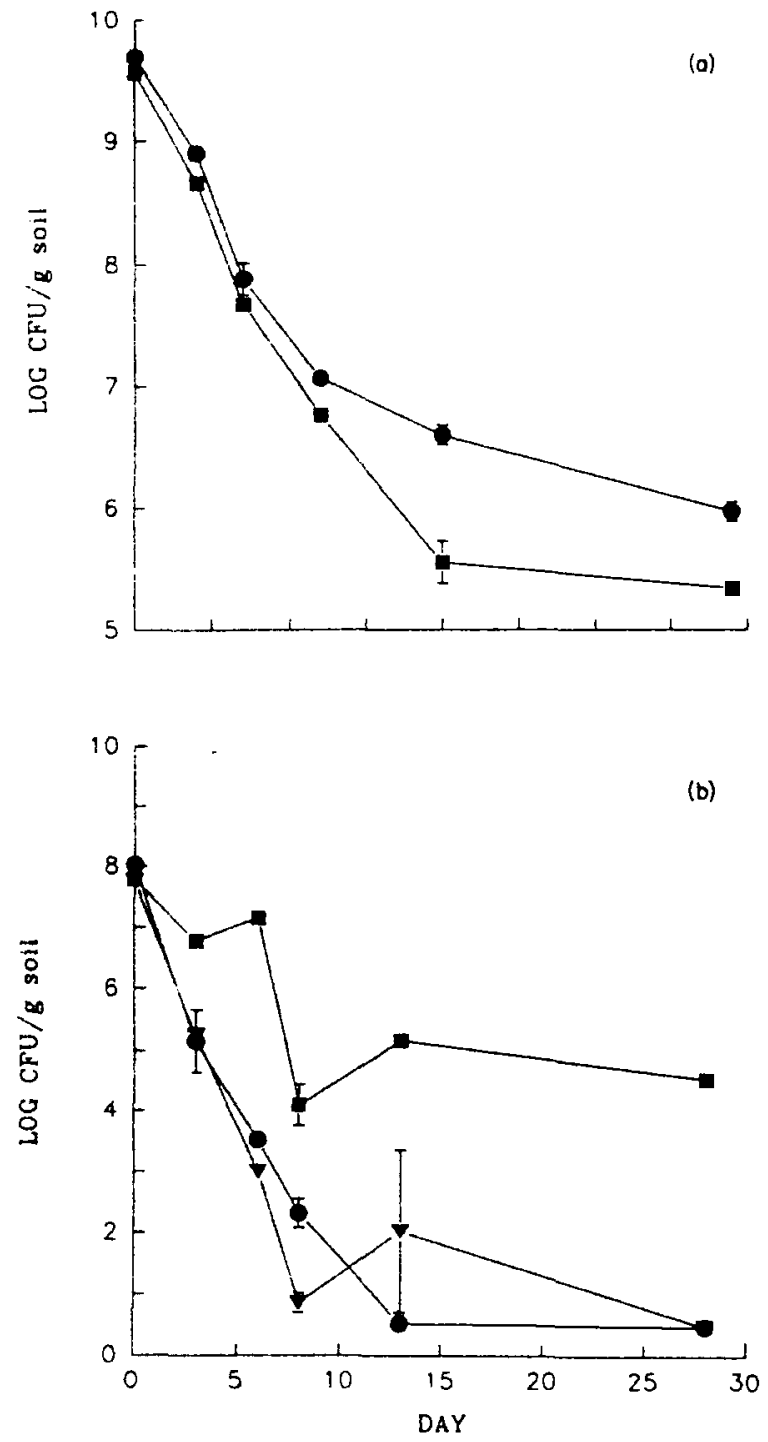

Fig. 2 Numbers of $P$. putida PP0301 (O), P. putida PP0301(pR0101) ( $)$, and $P$. putida PP0301 (pRO103) (E) in (a) unamended agricultural soil and (b) the presence of $500-\mu \mathrm{g} / \mathrm{g}$ PAA. Plotted values are means \pm SEM. Some standard error bars fall within the area of the symbol.

was detected whilst PAA was detected at the initial concentration (data not shown).

A comparison of survival of $P$. putida PP0301, P. putida PP0301(pR0101) and P. putida PP0301(pR0103) in the presence and absence of PAA demonstrates that PAA is bacteriotoxic (Fig. 2). In unamended soil, survival of the parental strain P. putida PP0301 and the GEM strain P. putida PP0301(pR0103) were similar (Fig. 2a). When inoculated at approximately $10^{9}$ colony forming units (CFU)/g soil, P. putida PPO301 had declined to approximately $10^{6} \mathrm{CFU} / \mathrm{g}$ after 39 days in unamended soil. In PAA-amended soil, an initial inoculum density of
$P$. putida PP0301 at approximately $10^{8} \mathrm{CFU} / \mathrm{g}$ had declined to fewer than $3 \mathrm{CFU} / \mathrm{g}$ after 13 days (Fig. 2b). Survival of the inducible strain P. putida PP0301(pR0101) was similar to that of the parental strain $P$. putida PP0301 in unamended (data not shown) and PAA-amended soil. In contrast, the survival of the GEM strain P. putida PP0301(pR0103) was very similar in both unamended and PAA-amended soil, and strikingly different from the survival of the parental strain in PAA amended soil.

In a second study, the affect of PAA mineralization by P. putida PP0301(pR0103) was demonstrated biologically. Seeds of $R$. sativus were planted in native soil amended with $500-\mu \mathrm{g} / \mathrm{g}$ PAA in the presence and in the absence of cells of the constitutive PAA degrader. In the presence of P. putida PP0301(pR0103), $100 \%$ of the seeds (15 of 15) germinated. In uninoculated soil, only $7 \%$ of the seeds germinated.

\section{Discussion}

The results of these studies suggested that the PAA degrader P. putida PP0301(pR0103) had a selective advantage releative to either of the non-degraders of PAA (P. putida PP0301 and P. putida PP0301(PR0101)) in soil amended with PAA. P. putida PP0301(pR0103) expresses a chromosomally encoded phenol hydroxylase (Harker et al. 1989), which enables this GEM to mineralize PAA. In fact, $500-\mu \mathrm{g} / \mathrm{g}$ PAA was mineralized to less than $10 \mu \mathrm{g} / \mathrm{g}$ within 13 days (Fig. 1) without an accumulation of greater than $10-\mu \mathrm{g} / \mathrm{g}$ phenol. However, although P. putida PP0301( $\mathrm{PR0103)}$ can use PAA as a source of carbon, there was no apparent increased survival of $P$. putida PP0301(pR0103) in the presence of PAA, relative to unamended soil. Thus these data suggest that all strains of $P$. putida PP0301 experience toxicity to PAA and that the increased fitness of $P$. putida PP0301(pR0103), relative to $P$. putida strains PP0301 and P. putida PP0301(pR0101), was not due to some inherent resistance of PP0301( $\mathrm{PR} 0103$ ) to PAA. Rather, the increased fitness of $P$. putida PP0301(pR0103) in PAA-amended soil, relative to $P$. putida strains PP0301 and PP0301(pR0101), was due to its ability to degrade and thereby reduce the toxicity of PAA. In previous studies with the same soil type there was no significant difference in survival of $P$. putida PP0301 in unamended versus 2,4-D amended soil (Short et al. 1990). Newman (1947) evaluated the depressive effects of various phenoxy-herbicides on soil bacteria and fungi, and concluded that phenoyxacetatetype herbicides are inhibitory and taken up by cells only when in the undissociated form. The apparent higher toxicity of PAA, than 2,4-D, could therefore be explained if PAA passes through the cell membrane more easily than 2,4-D.

When induced by 2,4-D, P. putida PP0301(pR0101) and 
Alcaligenes eutrophus JMP134(pJP4) express a 2,4-D monooxygenase active on the non-inducing substrate PAA (Harker et al. 1989). If 2,4-D-degrading bacteria native to the Oregon farm soil express a similar 2,4-D monooxygenase, then we propose that the persistance of PAA in the agricultural soil, with a native microbiota capable of degrading 2,4-D (Short et al. 1990) indicates that PAA did not induce the expression of 2,4-D monooxygenase by the indigenous soil microbiota. Moreover, these results suggested that native 2,4-D degraders are induced in the presence of 2,4-D and corroborated evidence that the usual delay in 2,4-D degradation (Audus 1960; Altom \& Stritzke 1973), is the time necessary for enzyme induction (Audus 1960; Loos 1975). However, the fact that coamendment of soil with PAA and 2,4-D did not result in the degradation of $100-\mu \mathrm{g} / \mathrm{g}$ PAA after 40 days, although $500-\mu \mathrm{g} / \mathrm{g} 2,4-\mathrm{D}$ was degraded after 19 days, is supportive of an alternate possibility, that the enzyme systems of the indigenous 2,4-D degraders differ from plasmid PJP4 encoded enzymes in their substrate specificity.

\section{Acknowledgements}

This study was supported, in part, by the US Environmental Protection Agency-Corvallis Environmental Research Laboratory. It has been subjected to Agency review and approved for publication. Mention of trade names or commercial products does not constitute endorsement or recommendation for use.

\section{References}

Altenucher J, Schmid K, Schmitt R (1983) Tn1721-encoded tetracyline resistance: mapping of structural and regulatory genes mediating resistance. Journal of Bacteriology, 153, 116-123.

Altom JD, Stritzke JF (1973) Degradation of dicamba, picloram, and four phenoxy herbicides in soils. Weed Science, 21, 556-560.

Audus LJ (1960) Microbiological breakdown of herbicides in soils. In: Woodford EK, Sagar GR (eds) Herbicites and the Soil, pp. 1-19. Blackwell Scientific Publications, Oxford.

Cole DJ, Loughman BC (1982) Metabolism of phenoxyacetic acid in potato (Solanum tuberosum L.) tuber slices. Plant Science Letters, 27, 289-298.

Don RH, Pemberton JM (1981) Properties of six pesticide degradation plasmids isolated from Alcaligenes paradoxus and Alcaligenes eutrophus. Journal of Bacteriology, 145, 681-686.

Don RH, Weightman AJ, Knackmuss H-J, Timmis KN (1985) Transposon mutagenesis and cloning analysis of the pathways for degradation of 2,4-dichlorophenoxy- acetic acid and 3-chlorobenzoate in Alcaligenes eutrophus JMP134(pJP4). Journal of Bacteriology, 161, 85-90.

Doyle JD, Short KA, Stotzky G, King RJ, Olsen RH (1991) Ecologically significant effects of Pseudomonas putida PP0301 (pR0103), genetically engineered to degrade 2,4-dichlorophenoxyacetate, on microbial populations and processes in soil. Canadian Joumal of Microbiology, 37, 682-691.

Harker AR, Olsen RH, Seidler RJ (1989) Phenoxyacetic acid degradation by the 2,4-dichlorophenoxyacetic acid (TFD) pathway of plasmid PJP4: mapping and characterization of the TFD regulatory gene, ifdA. Journal of Bacteriology, 171, 314-320.

Jensen DJ (1978) Pesticide residue analysis. In: Moye HA (ed.) Monograph Series On Analytical Chemistry and its Application, No. 43, pp. 196-220. Interscience, New York.

Kaphammer B, Kukor JK, Olsen RH (1990) Regulation of $t f d$ CDEF by $t f d R$ of the 2,4-dichlorophenoxyacetic acid degradation plasmid PJP4. Journal of Bacteriology, 172, 2280-2286.

King RJ, Short KA, Seidler RJ (1991) Assay for detection and enumeration of genetically engineered microorganisms which is based on the activity of a deregulated 2,4-dichlorophenoxyacetate monooxygenase. Applied and Environmental Microbiology, 57, 1790-1792.

Loos MA (1975) Phenoxyalkanoic acids. In: Kearney PC, Kaufman DD (eds) Herbicides Chemistry, Degradation, and Mode of Action. Vol. 1. Marcel Dekker, New York.

Newman AS (1947) The effect of certain plant growthregulators on soil microorganisms and microbial processes. Soil Science Society of America Proceedings, 12, 217-221.

Olsen RH, Shipley P (1973) Host range and properties of the Psuedomonas aeruginosa R factor R1822. Journal of Bacteriology, 113, 772-780.

Orchard VA, Cook FJ (1983) Relationship between soil respiration and soil moisture. Soil Biology and Biochemistry, 15, 447-453.

Ou LT, Rothwell DF, Wheeler WB, Davidson JM (1978) The effect of high 2,4-D concentrations on degradation and carbon dioxide evolution in soils. Journal of Environmental Quality, 7, 241-246.

Pemberton JM, Corney B, Don RH (1979) Evolution and spread of pesticide degrading ability among soil microorganisms. In: Timmis KN, Puhler A (eds) Plasmids of Medical, Environmental and Commercial Importance. Elsevier, Amsterdam.

Purkayastha R (1974) Simultaneous determination of 2,4-dichlorophenoxyacetic acid, 2,4,5-trichlorophenoxyacetic acid, and 2-methoxy-3,6-dichlorobenzoic acid in soil and water by gas chromatography with electron capture detector. Journal of Agricultural and Food Chemistry, 22, 453-458. 
Sattar MA, Paasivirta J (1980) Fate of chlorophenoxyacetic acids in acid soil. Chemosphere, 9, 745-752.

Short KA, Seidler RJ, Olsen RH (1990) Survival and degradative capacity of Pseudomonas putida induced or constitutively expressing plasmid-mediated degradation of 2,4-dichlorophenoxyacetate (TFD) in soil. Canadian Journal of Microbiology, 36, 821-826.

Short KA, Doyle JD, King RJ, Seidler RJ, Olsen RH (1991) Effects of 2,4-dichlorophenol, a metabolite of a genetically engineered bacterium, and 2,4-dichlorophenoxyacetate on some microorganism-mediated ecological processes in soil. Applied and Environmental Microbiology, 57, 412-418.

Smith AE Jr, Shuman LM, Lokey N (1984) High-pressure liquid chromatographic analysis of tebuthiuron in soil. Journal of Agricultural and Food Chemistry, 32, 416-418.

Stanier RY, Palleroni NJ, Doudoroff M (1966) The aerobic pseudomonads: a taxonomic study. Journal of General Microbiology, 43, 159-271.

Steel RGD, Torrie JH (1980) Principles and Procedures of Statistics: a Biometrical Approach. MoGraw-Hill, New York.
Stott DE, Martin JP, Focht DD, Haider K (1983) Stabilization in humus, and incorporation into soil biomass of 2,4-D and chlorocatechol carbons. Soil Science Society of America Journal, 47, 66-70.

Streber WR, Timmis KN, Zenk MH (1987) Analysis, cloning, and high-level expression of 2,4-dichlorophenoxyacetate monoxygenase gene tfdA of Alcaligenes eutrophus JMP134. Journal of Bacteriology, 169, 29502955.

This paper is the result of a collaboration between K.A. Short, R.H. Olsen (University of Michigan) and R.J. Seidler, R.J. King (USEPA, Corvallis). The work was conducted in Corvallis while K.A. Short was a University of Michigan post-doctoral fellow/ visiting scientist at the USEPA Microbial Ecology/Biotechnology group. R.J. King is a chemist with a contract firm working in the Corvallis laboratory. This work was funded by a grant from the USEPA to R.H. Olsen. 